\begin{tabular}{|c|c|c|}
\hline \multirow{3}{*}{$\begin{array}{r}\text { Case Reports in } \\
\text { Gastroenterology }\end{array}$} & \multirow{2}{*}{\multicolumn{2}{|c|}{ Case Rep Gastroenterol 2017;11:748-754 }} \\
\hline & & \\
\hline & $\begin{array}{l}\text { DOI: 10.1159/000484661 } \\
\text { Published onlIne: November 29, } 2017\end{array}$ & $\begin{array}{l}\text { (c) } 2017 \text { The Author(s) } \\
\text { Published by S. Karger AG, Basel } \\
\text { www.karger.com/crg }\end{array}$ \\
\hline & $\begin{array}{l}\text { This article is licensed under the } \mathrm{Cr} \\
\text { International License (CC BY-NC) (ht } \\
\text { Usage and distribution for commercial }\end{array}$ & $\begin{array}{l}\text { nons Attribution-NonCommercial } 4.0 \\
\text { ger.com/Services/OpenAccessLicense). } \\
\text { uires written permission. }\end{array}$ \\
\hline
\end{tabular}

\title{
Routine Treatment-Resistant Clostridium difficile Infection during Recovery from Myxedema
}

\author{
Jan K. Adamski $\quad$ Björn B. Jäschke ${ }^{a} \quad$ Raija S. Uusitalo-Seppäläb \\ Kalle V.J. Moilanen ${ }^{c}$ Antti V. Pehkonen ${ }^{a}$ Wojciech Weigl ${ }^{d}$ \\ aDepartment of Anaesthesiology and Intensive Care, Satakunta Central Hospital, \\ Pori, Finland; 'bepartment of Infectious Diseases, Satakunta Central Hospital, \\ Pori, Finland; 'Department of Gastroenterology, Satakunta Central Hospital, Pori, Finland; \\ ${ }^{\mathrm{d}}$ Anaesthesiology and Intensive Care, Department of Surgical Sciences, Uppsala \\ University, Akademiska Hospital, Uppsala, Sweden
}

\section{Keywords}

Clostridium difficile - Myxedema · Hypothyroidism - Thyroid insufficiency · Clostridial infection .

Enterocolitis · Fecal microbiota - Transplantation

\begin{abstract}
Development of the extreme form of hypothyroidism defined as myxedema is very rare. Acute symptoms and their management have been described in detail previously. However, not much attention has been devoted to therapeutic challenges that are faced in the recovery phase of the treatment, especially pertaining to the gastrointestinal system. The link between myxedema and the appearance of severe Clostridium difficile infection (CDI) has not been established so far. A 61-year-old woman with no significant medical record was admitted to hospital because of infected heel pressure and thyroid dysfunction. A week later, due to hypothermia, hypotension, and unconsciousness, she was transferred to the intensive care unit. The clinical picture and the results of laboratory tests confirmed diagnosis of myxedema. After the introduction of resuscitative measures and hormonal substitution, patient's condition stabilized within 10 days. Due to concomitant sepsis, initially piperacillin/tazobactam and later cefuroxime were administered. After 20 days of antibiotic therapy, the patient developed CDI that was resistant to the routine mode of treatment. The clinical recovery was
\end{abstract}


achieved only after a fecal microbiota transplantation procedure. The function of the digestive tract in myxedema is disturbed by gastric achlorydia and reduced peristalsis, which in turn can predispose the small intestine to overgrowth of bacteria. The use of antibiotics can additionally decrease the intestinal bacterial diversity, favoring the overgrowth of Clostridium difficile. The authors conclude that myxedema may increase the likelihood of a treatmentresistant form of $\mathrm{CDI}$ that requires the implementation of fecal microbiota transplantation.

(C) 2017 The Author(s)

Published by S. Karger AG, Basel

\section{Introduction}

Hypothyroidism is a common clinical problem, with reported prevalence of 3-6\%, depending on studied population [1]. The long-term consequences of severe thyroid dysfunction result in profound dysfunction of multiple vital organs including those of the respiratory, digestive, cardiovascular, hematopoietic, nervous, and musculoskeletal systems [2]. The disease is commonly diagnosed at an early stage; however, the development of extreme form of hypothyroidism defined as myxedema is very rare and typically results from neglected treatment of a previously diagnosed thyroid insufficiency [3]. Acute symptoms of myxedema present as a decreased level of consciousness, hypothermia, bradycardia, and hypotension. Other typical concomitant clinical symptoms, which develop over time during exacerbation of thyroid insufficiency, include coarse skin, facial edema, thin hair on the head, and pitting edema of the lower extremities [4].

The clinical description of severe thyroid insufficiency classification and recommendations for management are widely available in the literature [5]. However, these descriptions and recommendations mostly concentrate on problems that appear during the acute phase of the disease.

Here, we present a difficult-to-treat Clostridium difficile infection (CDI) that occurred in a patient during recovery from myxedema, when the physiological serum levels of thyroid hormones had already been reached. Despite advances in methods of treatment, CDI remains a significant epidemiological problem that is associated with increased mortality [6]. However, the clinical situations in which there is a high probability of the occurrence of CDI infections that are resistant to routine treatment have not yet been clearly defined.

\section{Materials and Methods}

A 61-year-old woman with no significant medical history presented to our hospital because of general weakness, which resulted in a fall at home. Initial finding was an infected heel pressure ulcer, for which the patient was admitted to the Department of General Surgery for further treatment. During the stay at this department, she also showed clinical signs of urinary tract infection and thyroid dysfunction. Six days later, due to hemodynamic instability and loss of consciousness, the patient was admitted to the intensive care unit (ICU). She was intubated on arrival. The patient was unconscious, hypothermic (temperature $35.8^{\circ} \mathrm{C}$ ), and hemodynamically unstable (i.e., hypotensive [systolic blood pressure $75 \mathrm{~mm}$ $\mathrm{Hg}$ ] and bradycardic [heart rate 45 beats per min]).

On physical examination, the patient was found to be obese (body mass index of 36), with generalized subcutaneous edema that was particularly marked in the lower limbs where large areas of macerated skin were present. The extensive heel pressure ulcer re- 
quired further surgical revision. The abdomen was soft with inaudible peristalsis and the presence of irreducible ventral hernia but with no features of occlusion.

Laboratory results showed: significant hypercapnia accompanied by compensated respiratory acidosis (arterial blood $\mathrm{pH}$ of 7.36 and elevated serum bicarbonate $\left[\mathrm{HCO}_{3} ; 32\right.$ $\mathrm{mEq} / \mathrm{L}]$ ), electrolyte disturbances (i.e., hypomagnesemia $[0.5 \mathrm{mmol} / \mathrm{L}]$, hypophosphatemia [0.4 mmol/L]), severe hypoalbuminemia (20 g/L), a C-reactive protein (CRP) level of 34 $\mathrm{mg} / \mathrm{L}$, and a white blood cell (WBC) count of $5.7 \times 10^{9}$ cells/L. Thyroid function tests (thyroxine [T4], $1.0 \mathrm{nmol} / \mathrm{L}$; thyroid-stimulating hormone $[\mathrm{TSH}]>100 \mathrm{mU} / \mathrm{L}$ ) indicated extreme thyroid insufficiency, which was identified as myxedema.

Along with fluid resuscitation and inotropic support, hormonal substitution was initiated (i.e., intravenous T4 $500 \mu$ g given initially, and then continued with T4 $100 \mu \mathrm{g} /$ day plus intravenous triiodothyronine [T3] $5 \mu \mathrm{g} \times 3$ /day). Due to suspected sepsis (with source in urinary tract infection and heel pressure ulcer), the initial empirical intravenous piperacillin/tazobactam therapy ( $4 \mathrm{~g} \times 3 /$ day) was started and then replaced after 4 days with a combination of intravenous cefuroxime $(1.5 \mathrm{~g} \times 3 /$ day) and metronidazole $(500 \mathrm{mg} \times 3$ / day). Metronidazole was withdrawn 3 days later. The urine culture and material taken from the lower limb wound indicated considerable growth of Escherichia coli and Corynobacterium, respectively.

After hemodynamic stabilization, the intravenous hormonal medication (T4 and T3) was reduced gradually and finally replaced with oral T4 when serum thyroid hormones were normalized (i.e., 10 days after the admission to the ICU). At the same time, the patient was extubated. Due to the gradual increase in CRP level $(156 \mathrm{ng} / \mathrm{L})$, and the emergence of clinical and radiological signs of pneumonia, cefuroxime was replaced with intravenous piperacillin/tazobactam ( $4 \mathrm{~g} \times 3$ /day). Over the next 3 days, the CRP level further increased (to $206 \mathrm{ng} / \mathrm{L}$ ), which was not accompanied by fever or an increase in WBC count.

The abdomen was still silent and moderately distended at this point. Because since admission there were no signs of bowel movement despite previously initiated enteral nutrition, computed tomography (CT) was performed. CT scans of the abdomen indicated the presence of a considerable amount of fecal content in the colon and rectum that resulted in its significant expansion (up to $9 \mathrm{~cm}$ in diameter; Fig. 1). In addition, the presence of enhancement and edema of sigmoid and rectal wall was identified (Fig. 2). Due to diagnosed bowel obstruction, enemas were instituted to relieve patient from residual fecal masses and to stimulate colon movement. Unexpectedly, after the administration of the enema, we observed violent and abundant diarrhea, which led to inspection of CDI. Soon after, 20 days after admission to hospital and introduction of antibiotic therapy, the diagnosis of CDI was confirmed by using a polymerase chain reaction (PCR) test for detecting enzymes produced by toxigenic Clostridium difficile in stools (BD MAX Cdiff assay; BD Diagnostic Systems). The high virulence of the detected strain was excluded with the use of other PCR tests (GeneXpert; Cepheid). Initially, enteral vancomycin (250 mg $\times 4 /$ day) was started but due to persistent diarrhea, it was replaced 4 days later with intravenous metronidazole (500 $\mathrm{mg} \times 3$ / day), enteral fidaxomicin (200 $\mathrm{mg} \times 2 /$ day), and intravenous tigecycline $(100 \mathrm{mg}$ given initially and continued with $50 \mathrm{mg} \times 2 /$ day). The piperacillin/tazobactam medication was stopped. Despite this antibiotic treatment, there was no clinical improvement over the next week.

Due to the lack of response to implemented treatment and after confirmation the diagnosis of CDI in the macroscopic findings of colonoscopy (i.e., extensive swelling of the mucous membrane without accompanying pseudomembranous formations), a fecal microbiota transplant was performed using frozen stool from an unrelated healthy donor. One of the 
donor's relatives had been treated for recurrent Clostridium difficile in the past, and therefore, the donor had previously been screened for bacterial pathogens and parasites (using the previously published protocol [7]). During the transplantation procedure, $500 \mathrm{~mL}$ of a liquid suspension of donor stool was provided to the patient through 5 enema portions $[100$ $\mathrm{mL}$ per portion). Within $48 \mathrm{~h}$ after the procedure was completed, the symptoms of diarrhea disappeared, no adverse effects were noticed and a rapid decrease in CRP levels followed. The further prolonged recovery from myxedema was continued without any problems from the digestive tract. Finally, the patient was discharged to the ordinary ward after 65 days spent in the ICU.

\section{Discussion}

Despite advances in methods of treatment, CDI remains a significant epidemiological problem that is associated with increased mortality rate ranging from 6 to $30 \%[6,8]$. Together with another risk factor, i.e., myxedema (mortality rate of approximately $30-50 \%$ [3, 4]), it posed a therapeutic challenge in our ICU, where previously reported mortality rate in patients with metabolic disorders was 6.7\% [9].

Most myxedema cases are provoked by infections and septicemia that occur in the course of severe hypothyreosis [4]. In the presented case, we found that the identification of myxedema was accompanied by an infection that required antibiotic treatment. Prolonged use of antibiotics is a well-recognized risk factor for CDI [6]. Clostridium difficile is an anaerobic toxin-producing gram-positive spore bacterium that can manifest clinically as colitis and diarrhea $[6,10]$. Here, CDI was diagnosed based on clinical features (i.e., diarrhea with colitis), evidence of toxin-producing Clostridium difficile in stools confirmed with PCR tests, and the colonoscopy findings. Severe CDI is usually accompanied by WBC higher than $15 \times$ $10^{9}$ cells/L as reported previously [11]. In laboratory findings, the rise in CRP was not accompanied by a rise in WBC; however, immune response could have been inhibited due to the prolonged effect of thyroid dysfunction [12]. Because the patient failed to respond to administered routine antibiotic treatment, a fecal microbiota transplantation procedure was required. This method has recently found acceptance as a safe and effective treatment of recurrent CDI [11,13] and other bowel inflammatory diseases [14]. The theoretical foundation behind fecal microbiota transplantation is the assumption that a disorder of the intestinal flora both underlies and accompanies the disease. As a result of such a procedure, the normal intestinal flora is restored and the Clostridium difficile bacteria are removed [15]. According to recently published European Society of Clinical Microbiology and Infectious Diseases guidelines, fecal microbiota transplantation is indicated in a situation of multiple recurrent CDI [16]. However, there is an increasing number of publications reporting successful use of fecal microbiota transplantation in severe cases of CDI not responding to conventional antibiotic treatment [17] and our case report confirms such alternative.

Risk factors for CDI include, but are not limited to, concomitant antibiotics, anti-motility medication, hypoalbuminemia, and gastric acid suppression medication [13]. Hypothyroidism influences the function of the digestive tract by causing gastric achlorydia and reducing peristalsis, which in turn can predispose the small intestine to overgrowth of bacteria [18]. Association between thyroid insufficiency and a decrease in stool frequency, an occurrence of paralytic ileus megacolon, pseudoobstruction, ischemia, and volvulus have already been documented [19]. Clostridium difficile is a common pathogen that is often found in intestinal bacteria overgrowth [20]. In the described case, the prior use of antibiotics could additional- 
Adamski et al:: Routine Treatment-Resistant Clostridium difficile Infection during Recovery from Myxedema

ly decrease the intestinal bacterial diversity, thereby favoring the massive overgrowth of Clostridium difficile. In such a situation, the probability of developing a severe form of CDI increases.

At present, hypothyroidism is detected and treated in the early stages, which limits its effect on gastrointestinal function. This may explain the lack of reports in the literature that suggest a possible vulnerability of hypothyroid patients for the occurrence of treatmentresistant acute CDI-associated diarrhea. However, the myxedema, which is an extreme form of thyroid dysfunction, may predispose patients to the occurrence of a severe form of CDI that requires fecal microbiota transplantation.

\section{Statement of Ethics}

The authors have no ethical conflicts to disclose. Patient consent was obtained.

\section{Disclosure Statement}

The authors have nothing to disclose.

\section{References}

1 Golden SH, Robinson KA, Saldanha I, Anton B, Ladenson PW: Clinical review: Prevalence and incidence of endocrine and metabolic disorders in the United States: a comprehensive review. J Clin Endocrinol Metab 2009;94:1853-1878.

2 Wiersinga WM: Adult hypothyroidism; in De Groot LJ, Chrousos G, Dungan K, Feingold KR, Grossman A, Hershman JM, Koch C, Korbonits M, McLachlan R, New M, Purnell J, Rebar R, Singer F, Vinik A (eds): Endotext. South Dartmouth (MA), 2000.

3 Chiong YV, Bammerlin E, Mariash CN: Development of an objective tool for the diagnosis of myxedema coma. Transl Res 2015;166:233-243.

4 Mathew V, Misgar RA, Ghosh S, Mukhopadhyay P, Roychowdhury P, Pandit K, Mukhopadhyay S, Chowdhury S: Myxedema coma: a new look into an old crisis. J Thyroid Res 2011;2011:493462. Wartofsky L: Myxedema coma. Endocrinol Metab Clin North Am 2006;35:687-698, vii-viii. Leffler DA, Lamont JT: Clostridium difficile infection. N Engl J Med 2015;372:1539-1548.

Mattila E, Uusitalo-Seppala R, Wuorela M, Lehtola L, Nurmi H, Ristikankare M, Moilanen V, Salminen K, Seppala M, Mattila PS, Anttila VJ, Arkkila P: Fecal transplantation, through colonoscopy, is effective therapy for recurrent Clostridium difficile infection. Gastroenterology 2012;142:490-496.

-8 Hota SS, Achonu C, Crowcroft NS, Harvey BJ, Lauwers A, Gardam MA: Determining mortality rates attributable to Clostridium difficile infection. Emerg Infect Dis 2012;18:305-307.

-9 Adamski J, Goraj R, Onichimowski D, Gawlikowska E, Weigl W: The differences between two selected intensive care units located in central and northern Europe - preliminary observation. Anaesthesiol Intensive Ther 2015;47:117-124.

10 Ofosu A: Clostridium difficile infection: a review of current and emerging therapies. Ann Gastroenterol 2016;29:147-154.

-11 Surawicz CM, Brandt LJ, Binion DG, Ananthakrishnan AN, Curry SR, Gilligan PH, McFarland LV, Mellow M, Zuckerbraun BS: Guidelines for diagnosis, treatment, and prevention of Clostridium difficile infections. Am J Gastroenterol 2013;108:478-498; quiz 499.

-12 Kawa MP, Grymula K, Paczkowska E, Baskiewicz-Masiuk M, Dabkowska E, Koziolek M, Tarnowski M, Klos P, Dziedziejko V, Kucia M, Syrenicz A, Machalinski B: Clinical relevance of thyroid dysfunction in human haematopoiesis: biochemical and molecular studies. Eur J Endocrinol 2010;162:295-305.

13 Khanna S, Pardi DS: Clostridium difficile infection: management strategies for a difficult disease. Therap Adv Gastroenterol 2014;7:72-86.

14 Xu L, Zhang T, Cui B, He Z, Xiang J, Long C, Peng Z, Li P, Huang G, Ji G, Zhang F: Clinical efficacy maintains patients' positive attitudes toward fecal microbiota transplantation. Medicine 2016;95:e4055. 


\section{Case Reports in Gastroenterology}

\begin{tabular}{l|l}
\hline Case Rep Gastroenterol 2017:11:748-754 \\
\hline DOI: 10.1159/000484661 & $\begin{array}{l}\text { @ 2017 The Author(s). Published by S. Karger AG, Basel } \\
\text { www.karger.com/crg }\end{array}$ \\
\hline
\end{tabular}

Adamski et al.: Routine Treatment-Resistant Clostridium difficile Infection during Recovery from Myxedema

15 Broecker F, Kube M, Klumpp J, Schuppler M, Biedermann L, Hecht J, Hombach M, Keller PM, Rogler G, Moelling K: Analysis of the intestinal microbiome of a recovered Clostridium difficile patient after fecal transplantation. Digestion 2013;88:243-251.

16 Crobach MJ, Planche T, Eckert C, Barbut F, Terveer EM, Dekkers OM, Wilcox MH, Kuijper EJ: European Society of Clinical Microbiology and Infectious Diseases: update of the diagnostic guidance document for Clostridium difficile infection. Clin Microbiol Infect 2016;22(suppl 4):S63-S81.

-17 van Beurden YH, Nieuwdorp M, van de Berg PJEJ, Mulder CJJ, Goorhuis A: Current challenges in the treatment of severe Clostridium difficile infection: early treatment potential of fecal microbiota transplantation. Therap Adv Gastroenterol 2017;10:373-381.

18 Daher R, Yazbeck T, Jaoude JB, Abboud B: Consequences of dysthyroidism on the digestive tract and viscera. World J Gastroenterol 2009;15:2834-2838.

19 Ebert EC: The thyroid and the gut. J Clin Gastroenterol 2010;44:402-406.

20 Patil AD: Link between hypothyroidism and small intestinal bacterial overgrowth. Indian J Endocrinol Metab 2014;18:307-309.

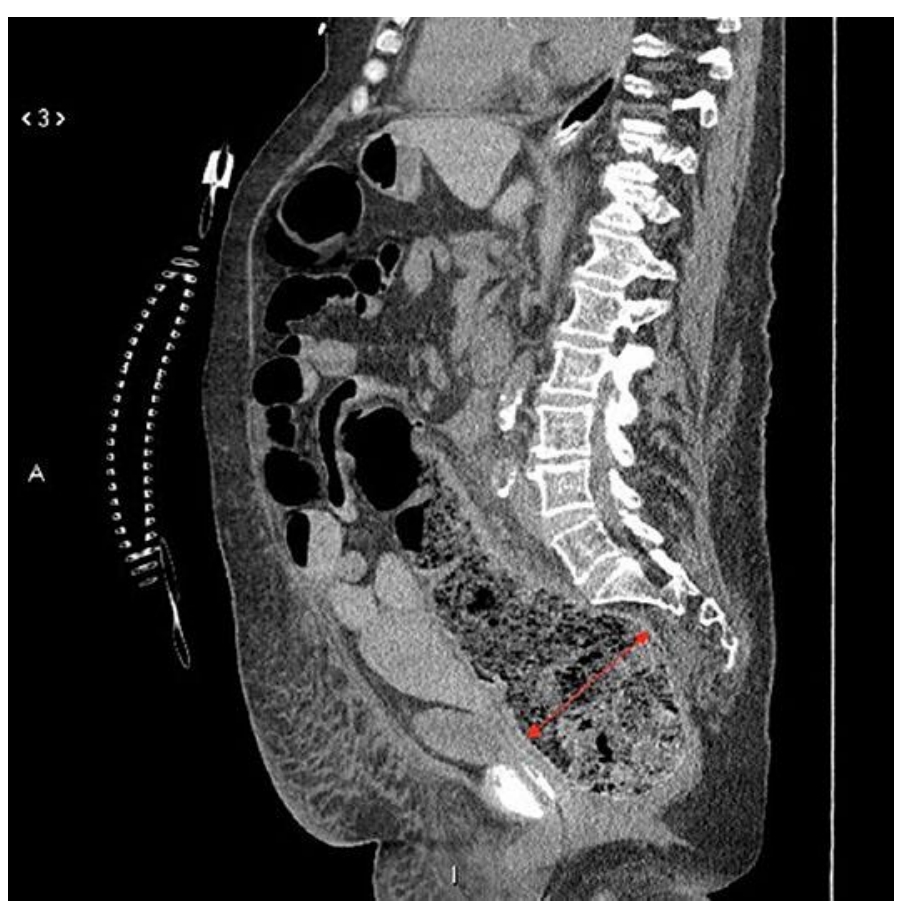

Fig. 1. The colon and rectum are widened and full of intestinal contents. The rectum shows significant enlargement, up to $9 \mathrm{~cm}$ in transverse diameter. 


\section{Case Reports in Gastroenterology Case Rep Gastroenterol 2017;11:748-754 \\ (c) 2017 The Author(s). Published by S. Karger AG, Basel www.karger.com/crg \\ Adamski et al.: Routine Treatment-Resistant Clostridium difficile Infection during Recovery from Myxedema}

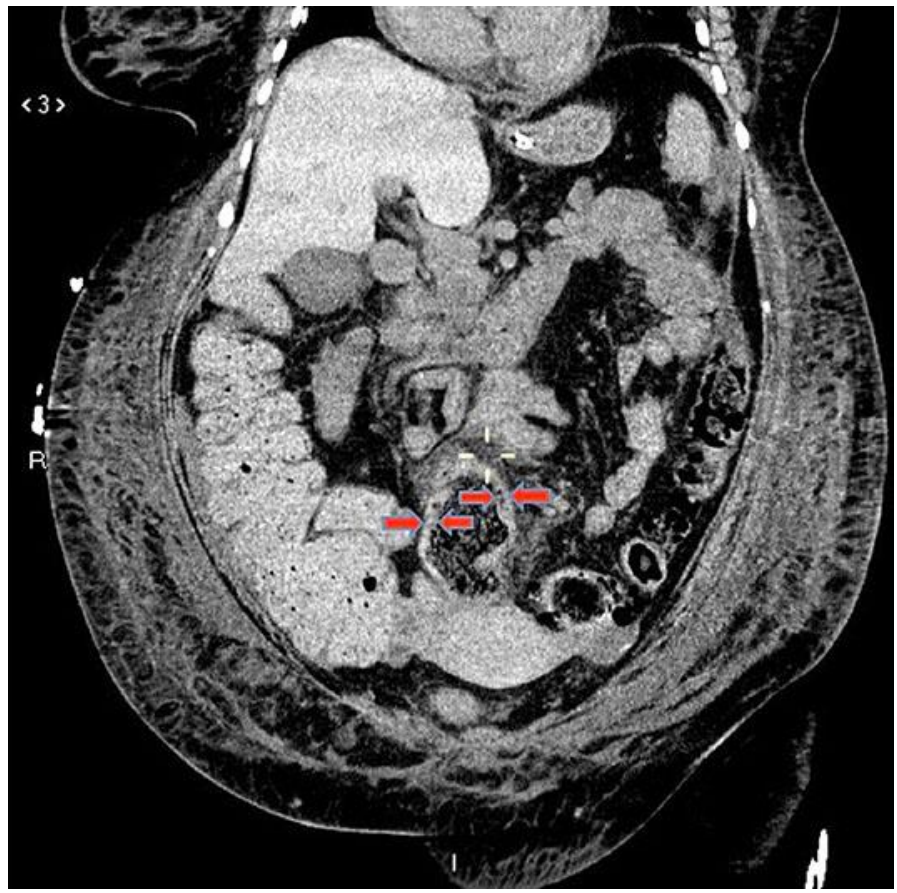

Fig. 2. The enhancement and edema of the sigmoid and rectal wall. 